\title{
Production of Poly(3-hydroxybutyrate) (P(3HB)) from Different Agroindustry Byproducts by Bacillus
}

\section{megaterium}

\author{
Guilherme de Souza Hassemer $^{1}{ }^{(\mathbb{D})}$, Rosicler Colet $^{1}{ }^{(\mathbb{D})}$, Rafaela Nery de Melo ${ }^{1}{ }^{(\mathbb{D})}$, Bruno Fischer $^{1}{ }^{(\mathbb{D})}$, Yen- \\ Han Lin ${ }^{2}(\mathbb{D})$, Alexander Junges ${ }^{1(\mathbb{D})}$, Eunice Valduga ${ }^{1, *}$ \\ 1 Department of Food Engineering, URI -Erechim Av. Sete de Setembro, 1621, Erechim, Rio Grande do Sul, Brazil, 99709- \\ 910, Brazil \\ 2 Department of Chemical Engineering, University of Saskatchewan, Saskatoon, SK S7 N 5A9, Canada \\ * Correspondence: veunice@ uricer.edu.br;
}

Scopus Author ID 23490413300

Received: 31.01.2021; Revised: 2.03.2021; Accepted: 4.03.2021; Published: 9.03.2021

\begin{abstract}
The use of plastics, replacing materials such as paper and glass, has become a staple of modern society. A possible alternative is the production of biopolymers, in which case polyhydroxyalkanoates (PHAs) tend to be the most studied class. Among the PHAs, poly(3hydroxybutyrate) $(\mathrm{P}(3 \mathrm{HB}))$ is one of the most studied. Bacillus megaterium can utilize a wide range of carbon sources to produce $\mathrm{P}(3 \mathrm{HB})$ and display high resistance to osmotic pressure and temperature. There are few studies regarding the viability of confectionery wastewater (CWW) and rice parboiling water (RPW) in PHA production; however, data suggests they might be successfully used as culture media for microorganisms. Cultures of $B$. megaterium were conducted under a $2^{2}$-factorial design of experiments with different agitation and airflow conditions using mineral medium added with CWW and RPW. Under maximized conditions, it was possible to obtain $7.55 \mathrm{~g} / \mathrm{L}$ of dry cell biomass, with $50.1 \% \mathrm{P}(3 \mathrm{HB})$ content $(3.78 \mathrm{~g} / \mathrm{L})$. Kinetic parameters of the maximized culture were also assessed, with the highest productivity $(0.146 \mathrm{~g} / \mathrm{L} \cdot \mathrm{h})$ being found after $20 \mathrm{~h}$ of culture. Results found in the tests indicate that CWW and RPW can be used as culture media in $\mathrm{P}(3 \mathrm{HB})$ production; however further studies are necessary to fully optimize the process, as well as to find alternatives to reduce the amount of residual total organic carbon (TOC) still present in the cultures.
\end{abstract}

Keywords: polyhydroxybutyrate; Bacillus megaterium; bioproduction; agroindustry; byproducts; confectionery wastewater; rice parboiling water.

(C) 2021 by the authors. This article is an open-access article distributed under the terms and conditions of the Creative Commons Attribution (CC BY) license (https://creativecommons.org/licenses/by/4.0/).

\section{Introduction}

The use of plastics, replacing materials such as paper and glass, has become a staple of modern society. Plastics tend to offer high durability, good mechanical properties, and low production cost. However, the plastic's durability also becomes an issue once it has been discarded. Conventionally there are two main ways to treat plastic waste, recycling and incineration, both of which have their disadvantages and issues [1-3].

A possible alternative is biopolymers' production, in which case polyhydroxyalkanoates (PHAs) tend to be the most studied class. PHAs are polyesters synthesized by microorganisms as an energy reserve. They are stored as amorphous crystals in the cells and may be consumed when the microorganism in question is under stress. Due to this, PHAs are completely biodegradable, being able to be consumed by many species of bacteria found in soil and water; 
on top of that, their mechanical properties tend to be similar to those of conventional nonbiodegradable polymers [4-6].

Among the PHAs, poly(3-hydroxybutyrate) $(\mathrm{P}(3 \mathrm{HB}))$ is one of the most studied. Many kinds of bacteria can synthesize it, with bacteria belonging to the genus Bacillus being potential large-scale products $[6,7]$. Among them, Bacillus megaterium was one of the first bacteria to be studied regarding its $\mathrm{P}(3 \mathrm{HB})$ production. They can utilize a wide range of carbon sources and display high resistance to osmotic pressure and temperature [8-13].

In the conventional production of $\mathrm{P}(3 \mathrm{HB})$, the most used substrates are pure glucose, molasses (beet, sugar cane), and syrups. However, considering their overall cost, something that has been questioned is the viability of byproducts from agroindustry processes as a viable carbon source in order to reduce production costs [14-22].

A process that generates a high volume of byproducts is the rice parboiling process. Brazil is the largest rice producer among American and European countries, with a reported harvest of 8.38 million tons in 2016/2017. The parboiling process is widely used in Brazil, and the water generated in the process is rich in minerals, with low $\mathrm{pH}$ and viscosity [23].

Another industry that generates an interesting byproduct is the confectionery industry. In 2018 more than 25 industries were operating in Brazil [24]. The most common byproducts come as wastewater from the cleaning of different machinery and equipment. These wastewaters are rich in sugars and/or fat, which may cause severe environmental damage if not properly treated $[25,26]$.

There are very few studies regarding the viability of these byproducts in PHA production; however, data suggests they might be successfully used as culture media for microorganisms $[27,28]$. As such, this study seeks to evaluate the viability of these byproducts as a culture media in the production of $\mathrm{P}(3 \mathrm{HB})$ by Bacillus megaterium ATCC 1451.

\section{Materials and Methods}

\subsection{Agroindustry byproducts.}

Two agroindustry byproducts were used in the present study, confectionery wastewater $(\mathrm{CWW})$ and rice parboiling water (RPW). CWW was obtained from Peccin Ltda (Erechim, Rio Grande do Sul, Brazil) and RPW was donated by Nelson Wendt Industries (Pelotas, Rio Grande do Sul, Brazil).

\subsection{Microorganism and culture media.}

Bacillus megaterium ATCC 14581 was used during this study. The bacterium was obtained from the André Tosello Foundation in Brazil. B. megaterium cells were cultivated using mineral medium containing $\mathrm{Na}_{2} \mathrm{HPO}_{4}(3.6 \mathrm{~g} / \mathrm{L}), \mathrm{KH}_{2} \mathrm{PO}_{4}(1.5 \mathrm{~g} / \mathrm{L}), \mathrm{FeSO}_{4} \cdot 7 \mathrm{H}_{2} \mathrm{O}$ $(0.05 \mathrm{~g} / \mathrm{L})$, citric acid $(0.1 \mathrm{~g} / \mathrm{L}) \quad \mathrm{CaCl}_{2} \cdot 2 \mathrm{H}_{2} \mathrm{O} \quad(0.01 \mathrm{~g} / \mathrm{L}), \quad \mathrm{MgSO} 4.7 \mathrm{H} 2 \mathrm{O} \quad(0.008 \mathrm{~g} / \mathrm{L})$. Furthermore, the mineral medium was added with $1 \mathrm{~mL} / \mathrm{L}$ of a micronutrient solution, which contained $\quad \mathrm{H}_{3} \mathrm{BO}_{3} \quad(300 \mathrm{mg} / \mathrm{L}), \quad \mathrm{CoCl}_{2} \cdot 6 \mathrm{H}_{2} \mathrm{O} \quad(200 \mathrm{mg} / \mathrm{L}), \quad \mathrm{ZnSO}_{4} \cdot 7 \mathrm{H}_{2} \mathrm{O} \quad(30 \mathrm{mg} / \mathrm{L})$, $\mathrm{MnCl}_{2} \cdot 4 \mathrm{H}_{2} \mathrm{O} \quad(30 \mathrm{mg} / \mathrm{L}), \quad\left(\mathrm{NH}_{4}\right)_{6} \mathrm{Mo}_{7} \mathrm{O}_{24} \cdot 4 \mathrm{H}_{2} \mathrm{O} \quad(30 \mathrm{mg} / \mathrm{L}), \quad \mathrm{NiSO}_{4} \cdot 7 \mathrm{H}_{2} \mathrm{O} \quad(30 \mathrm{mg} / \mathrm{L})$, $\mathrm{CuSO}_{4} \cdot 5 \mathrm{H}_{2} \mathrm{O}(10 \mathrm{mg} / \mathrm{L})[29]$.

Different concentrations of confectionery wastewater (CWW) and rice parboiling water (RPW) were added to the medium according to their carbon content. All culture medium compositions were also added with ammonium sulfate $(2 \mathrm{~g} / \mathrm{L})$ [29]. The medium was autoclaved at $121^{\circ} \mathrm{C}$ for $15 \mathrm{~min}$, with the nitrogen source being autoclaved separately to avoid 
Maillard browning reaction. Culture media was inoculated with $2 \%$ of its volume of $B$. megaterium cells standardized to an OD of $1.000(625 \mathrm{~nm})$. Total organic carbon (TOC) and total nitrogen (TN) were evaluated through a carbon and nitrogen analyzer (TOC-V CSH, Shimadzu, Japan) connected to an automatic injector. Data was collected via TOC Control-V software. All tests were run in triplicate.

\subsection{Bioreactor fermentation process.}

Bioreactor fermentations followed a $2^{2}$-factorial design, with different levels of agitation and airflow (Table 1).

Table 1. Independent variables and levels used in the $2^{2}$-factorial design for bioreactor production of $\mathrm{P}(3 \mathrm{HB})$.

\begin{tabular}{l|c|c|c|c|c}
\multirow{2}{*}{ Independent variables } & \multirow{2}{*}{ Code } & \multirow{2}{*}{ Unit } & \multicolumn{3}{|c}{ Levels } \\
\cline { 4 - 6 } & & & $\mathbf{- 1}$ & $\mathbf{0} *$ & $\mathbf{1}$ \\
\hline Airflow & $\mathrm{X}_{1}$ & $\mathrm{vvm}$ & 1.0 & 2.5 & 4.0 \\
\hline Agitation speed & $\mathrm{X}_{2}$ & $\mathrm{rpm}$ & 100 & 300 & 500 \\
* Center point repetitions. & & & & &
\end{tabular}

Bioreactor batches were run using a $2.0 \mathrm{~L}$ vessel (Biostat B, B. Braun Biotech International Co., Germany) containing $1.5 \mathrm{~L}$ of culture medium; the fermentation vessel is connected to a control unit that allows the adjustment and monitoring of the system's agitation speed. Airflow was also monitored using an air compressor (Inalar Compact, NS, Brazil), where air would be pumped into the system after passing through a $25 \mu \mathrm{m}$ pore size filter (Whatman PLC, United Kingdom) [30, 31].

The fermentation lasted for $32 \mathrm{~h}$ at $30^{\circ} \mathrm{C}$, with the evaluated parameters being total biomass $(\mathrm{g} / \mathrm{L}), \mathrm{P}(3 \mathrm{HB})$ content $(\mathrm{g} / \mathrm{L})$, total biomass vs. $\mathrm{P}(3 \mathrm{HB})(\%)$ and $\mathrm{pH}$. Furthermore, a new set of experiments using a static airflow value of $4 \mathrm{vvm}$ and different agitation speeds $(500,600$, and $700 \mathrm{rpm})$ was also conducted, based on the data obtained from the $2^{2}$-factorial design.

\subsection{Kinetic parameters of $P(3 H B)$ bioproduction.}

Aiming to better understand the bioreactor cultures' kinetic parameters, samples were taken in regular intervals from the bioreactor batches (at the end of the fermentation process, for preliminary tests, and every four hours for cultures run under maximized conditions). Conversion factors for TOC and TN into a product, as well as into cells (YP/Sc, YP/Sn, YX/Sc, and $\mathrm{YX} / \mathrm{Sn}$, respectively) were determined for the bioreactor batches. Furthermore, culture productivity for cell growth and $\mathrm{P}(3 \mathrm{HB})$, as well as instantaneous and specific conversion rates $\left(r_{\mathrm{x}}, r_{\mathrm{p}}, \mathrm{r}_{\mathrm{c}}, \mathrm{r}_{\mathrm{n}}, \mu_{\mathrm{x}}, \mu_{\mathrm{p}}, \mu_{\mathrm{c}}\right.$, and $\left.\mu_{\mathrm{n}}\right)$ were also determined during the study [30].

Conversion factors for COT into $\mathrm{P}(3 \mathrm{HB})\left(\mathrm{Y}_{\mathrm{P} / \mathrm{Sc}}\right), \mathrm{TN}$ into $\mathrm{P}(3 \mathrm{HB})\left(\mathrm{Y}_{\mathrm{P} / \mathrm{Sn}}\right)$, COT into cells $\left(\mathrm{Y}_{\mathrm{X} / \mathrm{Sc}}\right)$, TN into cells $\left(\mathrm{Y}_{\mathrm{X} / \mathrm{Sn}}\right)$ and the relationship between cells and $\mathrm{P}(3 \mathrm{HB})\left(\mathrm{Y}_{\mathrm{P} / \mathrm{X}}\right)$ were

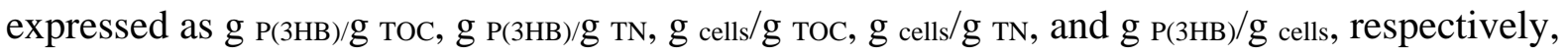
and calculated according to Eqs. (1) - (5) [30, 32].

$$
\begin{aligned}
& Y_{P / S c}=\frac{r_{p}}{r_{c}} \\
& Y_{P / S n}=\frac{r_{p}}{r_{n}} \\
& Y_{X / S c}=\frac{r_{x}}{r_{c}} \\
& Y_{X / S n}=\frac{r_{x}}{r_{n}}
\end{aligned}
$$




$$
Y_{P / X}=\frac{r_{p}}{r_{x}}
$$

In these equations, $r_{x}$ refers to the cell growth rate $(g / L . h), r_{n}$ is the NT consumption rate $(\mathrm{g} / \mathrm{L} . \mathrm{h}), r_{c}$ reflects the consumption rate of COT $(\mathrm{g} / \mathrm{L} . \mathrm{h})$, and $r_{p}$ represents $\mathrm{P}(3 \mathrm{HB})$ production rate $(\mathrm{g} / \mathrm{L} . \mathrm{h})$.

Furthermore, the specific rates of cellular growth $\left(\mu_{\mathrm{x}}\right)$, product formation $\left(\mu_{\mathrm{p}}\right)$, and substrate consumption $\left(\mu_{\mathrm{c}}\right.$ and $\left.\mu_{\mathrm{n}}\right)$ may be obtained by dividing the instantaneous conversion rates by the cell concentration, as shown in Eq. (6) [30, 32].

$$
\mu_{x}=\frac{r_{x}}{X}
$$

\subsection{Analytical determinations.}

\subsubsection{Total biomass.}

Total biomass was determined by centrifuging (MPW 351R Centrifuge, Rotor 11457, MPW Medical Instruments, Poland) $10 \mathrm{~mL}$ of culture at a speed of $3000 \mathrm{x} \mathrm{g}$ at $4^{\circ} \mathrm{C}$ for $15 \mathrm{~min}$. After the centrifugation process, the supernatant was removed and stored at $-20^{\circ} \mathrm{C}$ for further analysis. The precipitate was thoroughly washed with $10 \mathrm{~mL}$ of distilled water, resuspended, and centrifuged again under the same conditions. After the second centrifugation, the supernatant was discarded, and the precipitate was once again washed, resuspended, and centrifuged. After the third centrifugation cycle, the supernatant was once again discarded, and the precipitate was stored in an oven (NV-1.3, Nevo, Brazil) at $50^{\circ} \mathrm{C}$ until constant mass [33].

\subsection{2. $\mathrm{P}(3 \mathrm{HB})$ quantification.}

$\mathrm{P}(3 \mathrm{HB})$ content was quantified via gas chromatography (CG-2010, Shimadzu, Japan) equipped with an automatic injector (AOC-20i and AOC-20s) and a flame ionization detector (FID). Nitrogen was used as a carrier gas, with a flow rate of $2 \mathrm{~mL} / \mathrm{L}$. An Rtx-Wax $(30 \mathrm{~m} \times 0.25 \mathrm{~mm})$ capillary column was also used, with an initial temperature of $120^{\circ} \mathrm{C}$ in a heating ramp of $10^{\circ} \mathrm{C}$ pre-minute up to $190^{\circ} \mathrm{C}$. Injector and FID temperatures were kept at $250^{\circ} \mathrm{C}[22,34]$. Before each run, a calibration curve was constructed using standard (R)-3Hydroxybutyric acid (Sigma-Aldrich, Missouri, USA).

\subsection{Statistical Evaluation.}

During this study, the data were treated by analysis of variance (ANOVA) followed by Tukey's test. Pareto charts were also constructed to observe positive and negative effects on the studied variables. The software Statistic 5.0 (Statsoft, Oklahoma, USA) was used to treat all statistical data.

\section{Results and Discussion}

Table 2 presents the $2^{2}$-factorial design matrix, with real and codified values, and the results for dry biomass and $\mathrm{P}(3 \mathrm{HB})$.

The highest $\mathrm{P}(3 \mathrm{HB})$ concentration found was $3.57 \mathrm{~g} / \mathrm{L}$, with $7.10 \mathrm{~g} / \mathrm{L}$ of total biomass, when using $4 \mathrm{vvm}$ of $\mathrm{O}_{2}$ and $500 \mathrm{rpm}$ agitation speed (Assay 4). Assay 1, using both variables at their lowest levels, had the lowest amounts of dry biomass and $\mathrm{P}(3 \mathrm{HB})$ concentration $(0.095$ and $0.03 \mathrm{~g} / \mathrm{L}$, respectively). This behavior might be related to insufficient agitation speed, which does not allow for adequate $\mathrm{O}_{2}$ mixing, creating dead zones on the fermentation vessel 
[8, 35]. Faccin et al. [22] used B. megaterium DSM $32^{\mathrm{T}}$ to produce $\mathrm{P}(3 \mathrm{HB})$ using sucrose $(18 \mathrm{~g} / \mathrm{L})$ as the carbon source under similar conditions $\left(500 \mathrm{rpm}, 4 \mathrm{vvm}\right.$ of $\left.\mathrm{O}_{2}\right)$ and have obtained $4 \mathrm{~g} / \mathrm{L}$ of dry biomass, containing $0.4 \mathrm{~g} / \mathrm{L}$ of $\mathrm{P}(3 \mathrm{HB})$, considerably lower to what was found during this study. Omar et al. [36] evaluated large-scale $\mathrm{P}(3 \mathrm{HB})$ production using a strain of B. megaterium isolated from a water treatment plant in Saudi Arabia and 2\% date syrup as a carbon source. They were able to obtain $3.4 \mathrm{~g} / \mathrm{L}$ of dry biomass, with a $\mathrm{P}(3 \mathrm{HB})$ content of $25 \%(0.85 \mathrm{~g} / \mathrm{L})$, once again, significantly below what was found in the present study.

Table 2. $2^{2}$-factorial design matrix and results for dry biomass and $\mathrm{P}(3 \mathrm{HB})$ after $32 \mathrm{~h}$ culture.

\begin{tabular}{|c|c|c|c|c|c|}
\hline \multirow[b]{2}{*}{ Assay } & \multicolumn{2}{|c|}{ Independent variables* } & \multicolumn{3}{|l|}{ Response } \\
\hline & $\mathbf{X}_{1}$ & $\mathbf{X}_{2}$ & $\begin{array}{l}\text { Dry biomass } \\
(\mathrm{g} / \mathrm{L})\end{array}$ & $\begin{array}{l}\mathbf{P}(\mathbf{3 H B}) \\
(\mathbf{g} / \mathbf{L})\end{array}$ & $\begin{array}{l}\mathbf{P}(\mathbf{3 H B}) \\
(\%)\end{array}$ \\
\hline 1 & $-1(1)$ & $-1(100)$ & $0.95 \pm 0.150$ & $0.03 \pm 0.011$ & $3.92 \pm 0.179$ \\
\hline 2 & $1(4)$ & $-1(100)$ & $2.97 \pm 0.047$ & $1.29 \pm 0.080$ & $43.46 \pm 2.44$ \\
\hline 3 & $-1(1)$ & $1(500)$ & $6.20 \pm 0.141$ & $2.87 \pm 0.025$ & $47.03 \pm 0.414$ \\
\hline 4 & $1(4)$ & $1(500)$ & $7.10 \pm 0.200$ & $3.57 \pm 0.031$ & $50.43 \pm 0.804$ \\
\hline 5 & $0(2.5)$ & $0(300)$ & $4.97 \pm 0.125$ & $3.01 \pm 0.051$ & $57.87 \pm 2.830$ \\
\hline 6 & $0(2.5)$ & $0(300)$ & $5.03 \pm 0.125$ & $2.85 \pm 0.147$ & $57.59 \pm 3.540$ \\
\hline 7 & $0(2.5)$ & $0(300)$ & $5.07 \pm 0.170$ & $2.85 \pm 0.153$ & $55.35 \pm 1.350$ \\
\hline
\end{tabular}

Statistical evaluation of the data found that both agitation speed and airflow had positive impacts $(\mathrm{p}<0.05)$ on $\mathrm{P}(3 \mathrm{HB})$ and overall biomass content. Codified first-order models were constructed and validated via analysis of variance - ANOVA, with correlation coefficients of 0.932 and 0.844 for dry biomass and $\mathrm{P}(3 \mathrm{HB})$ content, respectively, as seen on Eqs. (10) - (11).

Dry biomass $(g / L)=4.61+2.34 . X_{2}$

$P(3 H B)(g / L)=2.35+1.28 . X_{2}$

Using these models, response surface and contour plots were constructed for both total dry biomass and $\mathrm{P}(3 \mathrm{HB})$ (Fig 1 and 2).

Based on the behavior found in the surface response and contour plots, it was noted that the maximum amount of dry biomass $(7.10 \mathrm{~g} / \mathrm{L})$ and $\mathrm{P}(3 \mathrm{HB})$ content $(3.57 \mathrm{~g} / \mathrm{L})$ were found in a range of $500 \mathrm{rpm}$ agitation speed, regardless of the airflow rate being used. Based on this assumption, a new set of experiments was run, using increased agitation speeds of 600 and $700 \mathrm{rpm}$. Airflow was kept at $4 \mathrm{vvm}$, as statistical analysis pointed out that it did not significantly influence $(p>0.05)$ the cultures. The results found during these experiments are presented in Table 3.
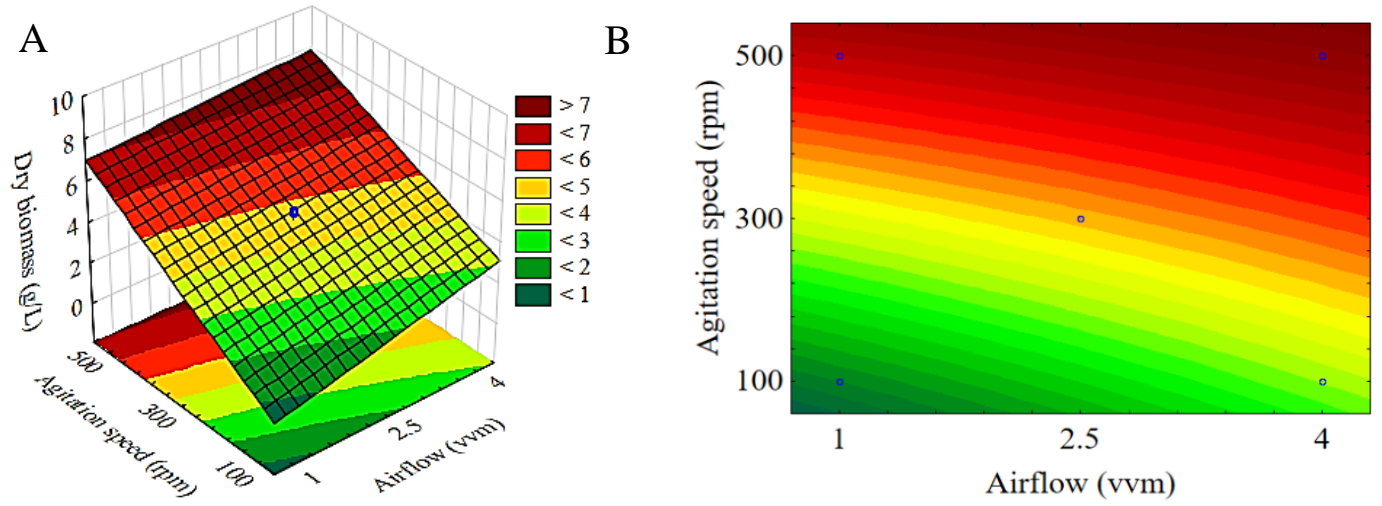

Figure 1. Response surface (A) and contour plot (B) of dry biomass production based on different agitation speeds and airflow rates. 

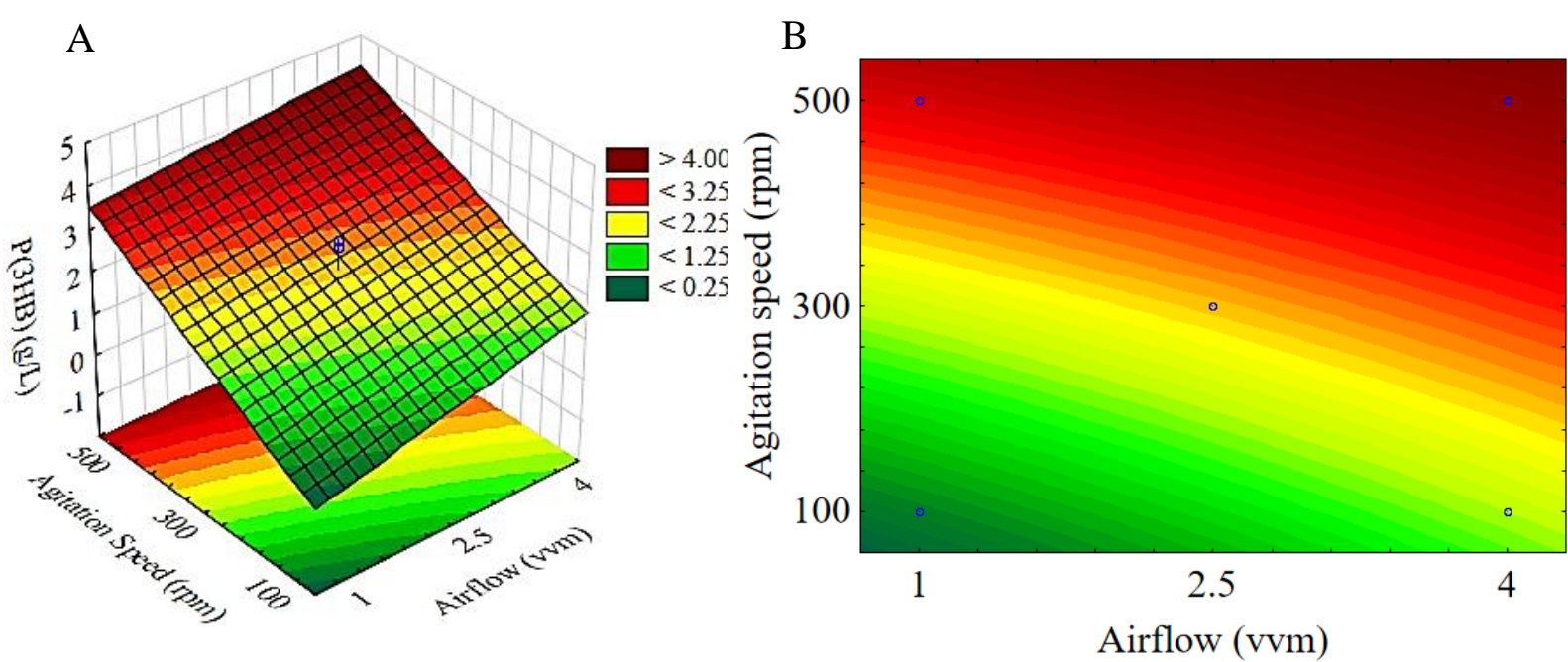

Figure 2. Response surface $(\mathrm{A})$ and contour plot $(\mathrm{B})$ of $\mathrm{P}(3 \mathrm{HB})$ production based on different agitation speeds and airflow rates.

The data found in these runs show that, by increasing agitation speed to $600 \mathrm{rpm}$, a reduction of approximately $24.6 \%$ of dry biomass was observed when compared to the run using $500 \mathrm{rpm}$. This reduction in dry biomass is even more prominent $(57.7 \%)$ when in the runs using $700 \mathrm{rpm}$ as the agitation speed.

Table 3. Concentration of dry biomass and $\mathrm{P}(3 \mathrm{HB})$ in bioreactor batches using agitation speeds ranging from 500 to $700 \mathrm{rpm}$.

\begin{tabular}{|c|c|c|c|c|}
\hline \multirow[b]{2}{*}{ Run* } & \multirow[b]{2}{*}{$\begin{array}{l}\text { Agitation speed } \\
\text { (rpm) }\end{array}$} & \multicolumn{3}{|l|}{ Results* } \\
\hline & & \begin{tabular}{|l|}
$\begin{array}{l}\text { Dry biomass } \\
(\mathrm{g} / \mathrm{L})\end{array}$ \\
\end{tabular} & \begin{tabular}{|l|}
$\mathbf{P}(3 \mathrm{HHB})$ \\
$(\mathrm{g} / \mathrm{L})$
\end{tabular} & \begin{tabular}{|l|}
$\mathbf{P}(3 \mathrm{HB})$ \\
$(\%)$ \\
\end{tabular} \\
\hline 1 & 500 & $7.10^{\mathrm{a}}(0.200)$ & $3.57^{\mathrm{a}}(0.031)$ & $50.43^{\mathrm{a}}(0.804)$ \\
\hline 2 & 600 & $5.35^{\mathrm{b}}(0.050)$ & $1.56^{\mathrm{b}}(0.050)$ & $30.04^{\mathrm{b}}(0.882)$ \\
\hline 3 & 700 & $4.10^{c}(0.100)$ & $0.318^{\mathrm{c}}(0.030)$ & $9.76^{\mathrm{c}}(0.504)$ \\
\hline
\end{tabular}

*Means (standard deviation) followed by identical letters are not statistically different ( $<<0,05$ - Tukey's test); $*$ Airflow $=4 \mathrm{vvm}$

Similarly, $\mathrm{P}(3 \mathrm{HB})$ content was extremely impacted by the increase in agitation speed compared to the runs that used an agitation speed of $500 \mathrm{rpm}$. Its concentration was reduced by $56.3 \%$ when using $600 \mathrm{rpm}$ and even further, by $91.1 \%$, when using $700 \mathrm{rpm}$. Kumar et al. [8], Grumezescu \& Holban [37], and Thomas, Balakrishnan \& Sreekala [21] all theorize that the main cause for such a substantial decrease in both dry biomass and $\mathrm{P}(3 \mathrm{HB})$ content is related to an increase in shear stress due to excessive agitation. Shear stress would damage the cells' membrane and, as a result, reduces cellular reproduction. Furthermore, since $\mathrm{P}(3 \mathrm{HB})$ is stored by $B$. megaterium as an energy reserve, such injuries would cause the cells to consume their energy reserves in order to repair the damage caused by shear stress, which would also explain the significant decrease in $\mathrm{P}(3 \mathrm{HB})$ production when using high agitation speeds. Based on the data found in this set of experiments, a kinetic profile of the condition that displayed the best results was constructed (Run 1: 500 rpm), as seen in Figure 3.

The data found using these culture conditions show that the culture had a short lag phase, with exponential growth starting at $4 \mathrm{~h}$ and going up to $8 \mathrm{~h}$. The highest dry biomass value found, however, was at $32 \mathrm{~h}$, with $7.55 \mathrm{~g} / \mathrm{L}$. For $\mathrm{P}(3 \mathrm{HB})$ production, the first quantifiable amount was found in samples taken at $8 \mathrm{~h}$, with approximately $0.68 \mathrm{~g} / \mathrm{L}$ of polymer $(12.2 \%$ of total dry biomass), while the highest yield being found at $32 \mathrm{~h}$, with $3.78 \mathrm{~g} / \mathrm{L}(50.1 \%$ of total dry biomass). Saratale et al. [38] have cultivated Lysinibacillus sp in minimal salts medium for 
$48 \mathrm{~h}$ and, when using sucrose as the carbon source, have obtained $1.44 \mathrm{~g} / \mathrm{L}$, their highest yield $(2.65 \mathrm{~g} / \mathrm{L})$ was found using glucose as the carbon source; however, both values are significantly lower to what was found during the present study. Kumar et al. [39] produced $\mathrm{P}(3 \mathrm{HB})$ from a mixed culture using deoiled algae biomass as the carbon source and, while their cell dry weight was not reported, the polymer amount they obtained was close to $43 \%$ of their dry biomass after $48 \mathrm{~h}$ of culture, similar to what was found in this study during the tests using $500 \mathrm{rpm}$.

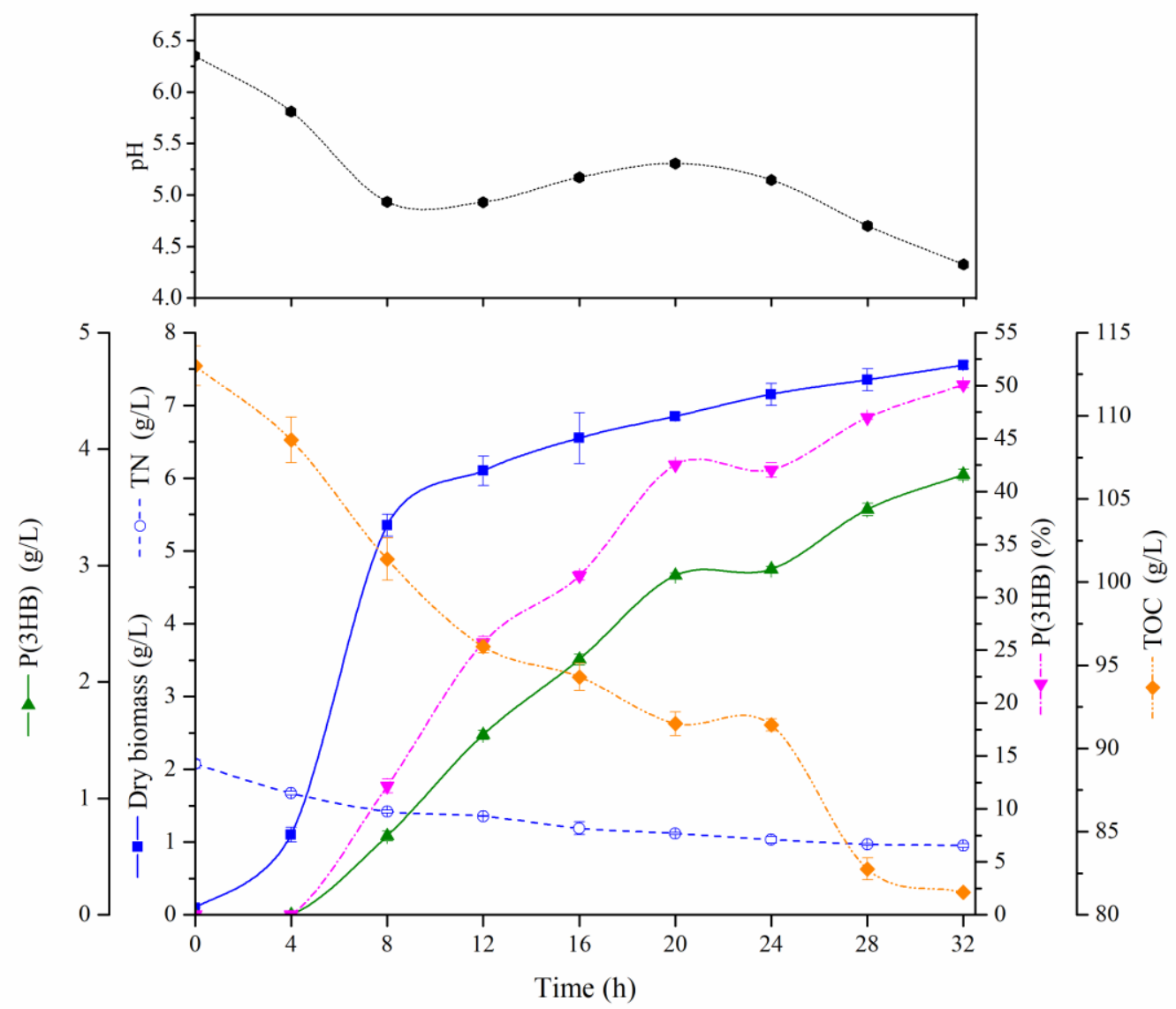

Figure 3. Kinetic profile for $\mathrm{pH}$, dry biomass, $\mathrm{P}(3 \mathrm{HB})$, and substrate consumption (TOC and $\mathrm{TN}$ ) using $500 \mathrm{rpm}$ agitation speed and $4 \mathrm{vvm} \mathrm{O}_{2}$ airflow.

Similarly, Amini et al. [40] have also found results similar to these. When the authors grew Cupriavidus necator in a culture media containing beer production wastewater added with maltose, after $120 \mathrm{~h}$, they obtained $7.9 \mathrm{~g} / \mathrm{L}$ of dry biomass and $3 \mathrm{~g} / \mathrm{L}$ of $\mathrm{P}(3 \mathrm{HB})$. Furthermore, Faccin et al. [22] have grown cultures of B. megaterium DSM $32^{\mathrm{T}}$ in mineral medium, using sucrose as the carbon source, under different volumetric oxygen mass transfer coefficients (kLa). After $32 \mathrm{~h}$, they obtained approximately $6 \mathrm{~g} / \mathrm{L}$ of dry biomass and $3 \mathrm{~g} / \mathrm{L}$ of $\mathrm{P}(3 \mathrm{HB})$. Jayakrishnan et al. [41] evaluated the influence of inoculum variation on $\mathrm{P}(3 \mathrm{HB})$ production from activated sludge and obtained approximately 7.8 to $14.4 \%$ of $\mathrm{P}(3 \mathrm{HB})$ by using different nutrients compositions, nearly 3.5 less than what has been found during this study.

Based on the data found in similar studies using different carbon sources, it becomes evident that CWW and RPW have a strong potential to be used as culture media in $\mathrm{P}(3 \mathrm{HB})$ production. In order to better understand that, kinetic parameters were calculated and are presented in Table 4. 
Table 4. Kinetic parameters for $\mathrm{P}(3 \mathrm{HB})$ production in bioreactor batches using $500 \mathrm{rpm}$ agitation speed and $4 \mathrm{vvm} \mathrm{O}_{2}$ airflow.

\begin{tabular}{|c|c|c|c|c|c|c|c|}
\hline$\underset{\text { (h) }}{\text { Time }}$ & $\begin{array}{c}\text { Cell } \\
\text { Productivity* } \\
(\mathrm{g} / \mathrm{L} \cdot \mathbf{h})\end{array}$ & $\begin{array}{c}\mathbf{P}(3 \mathbf{H B}) \\
\text { Productivity* } \\
(\mathrm{g} / \mathbf{L} \cdot \mathbf{h})\end{array}$ & $\begin{array}{c}\text { YP/Sc * } \\
(g / g)\end{array}$ & $\begin{array}{l}\text { YP/Sn* } \\
(\mathrm{g} / \mathrm{g})\end{array}$ & $\begin{array}{c}\mathbf{Y} \mathbf{X} / \mathbf{S c} * \\
(\mathrm{~g} / \mathrm{g})\end{array}$ & $\begin{array}{c}\text { Yx/Sn* } \\
(\mathrm{g} / \mathrm{g})\end{array}$ & $\begin{array}{c}\mu_{\mathbf{x}^{*}} \\
\left(\mathbf{h}^{-1}\right)\end{array}$ \\
\hline 0 & - & - & - & - & - & - & - \\
\hline 4 & $\begin{array}{c}0.251^{\mathrm{e}} \\
(0.035) \\
\end{array}$ & - & - & - & $\begin{array}{l}0.227^{\mathrm{d}} \\
(0.021) \\
\end{array}$ & $\begin{array}{c}2.50^{\mathrm{e}} \\
(0.045) \\
\end{array}$ & - \\
\hline 8 & $\begin{array}{r}0.657^{\mathrm{a}} \\
(0.027) \\
\end{array}$ & $\begin{array}{c}0.084^{\mathrm{d}} \\
(0.005) \\
\end{array}$ & $\begin{array}{c}0.058^{\mathrm{c}} \\
(0.003)\end{array}$ & $\begin{array}{c}1.04^{\mathrm{d}} \\
(0.124)\end{array}$ & $\begin{array}{c}0.452^{\mathrm{a}} \\
(0.015) \\
\end{array}$ & $\begin{array}{c}8.05^{\mathrm{b}} \\
(0.219)\end{array}$ & $\begin{array}{c}0.61^{\mathrm{a}} \\
(0.050) \\
\end{array}$ \\
\hline 12 & $\begin{array}{c}0.500^{\mathrm{b}} \\
(0.023) \\
\end{array}$ & $\begin{array}{l}0.129^{b} \\
(0.003) \\
\end{array}$ & $\begin{array}{c}0.092^{c} \\
(0.006) \\
\end{array}$ & $\begin{array}{c}2.17^{\mathrm{c}} \\
(0.113) \\
\end{array}$ & $\begin{array}{l}0.358^{\mathrm{b}} \\
(0.020) \\
\end{array}$ & $\begin{array}{c}8.41^{\mathrm{a}} \\
(0.166) \\
\end{array}$ & $\begin{array}{c}0.39^{\mathrm{b}} \\
(0.020) \\
\end{array}$ \\
\hline 16 & $\begin{array}{c}0.403^{\mathrm{c}} \\
(0.030) \\
\end{array}$ & $\begin{array}{l}0.137^{\mathrm{ab}} \\
(0.001)\end{array}$ & $\begin{array}{c}0.118^{\mathrm{b}} \\
(0.010)\end{array}$ & $\begin{array}{c}2.49^{\mathrm{bc}} \\
(0.131)\end{array}$ & $\begin{array}{l}0.347^{\mathrm{b}} \\
(0.019)\end{array}$ & $\begin{array}{c}7.34^{\mathrm{c}} \\
(0.229) \\
\end{array}$ & $\begin{array}{c}0.033^{\mathrm{c}} \\
(0.001) \\
\end{array}$ \\
\hline 20 & $\begin{array}{c}0.337^{\mathrm{d}} \\
(0.004)\end{array}$ & $\begin{array}{c}0.146^{\mathrm{a}} \\
(0.001)\end{array}$ & $\begin{array}{c}0.136^{\mathrm{a}} \\
(0.011) \\
\end{array}$ & $\begin{array}{c}3.05^{\mathrm{b}} \\
(0.109) \\
\end{array}$ & $\begin{array}{l}0.326^{c} \\
(0.021) \\
\end{array}$ & $\begin{array}{c}7.09^{\mathrm{cd}} \\
(0.261) \\
\end{array}$ & $\begin{array}{l}0.027^{\mathrm{c}} \\
(0.002)\end{array}$ \\
\hline 24 & $\begin{array}{l}0.294^{\mathrm{de}} \\
(0.008) \\
\end{array}$ & $\begin{array}{l}0.124^{\mathrm{b}} \\
(0.001) \\
\end{array}$ & $\begin{array}{c}0.138^{a} \\
(0.011) \\
\end{array}$ & $\begin{array}{c}2.85^{\mathrm{b}} \\
(0.056) \\
\end{array}$ & $\begin{array}{l}0.328^{c} \\
(0.017) \\
\end{array}$ & $\begin{array}{c}6.78^{\mathrm{d}} \\
(0.063) \\
\end{array}$ & $\begin{array}{l}0.023^{\mathrm{c}} \\
(0.002) \\
\end{array}$ \\
\hline 28 & $\begin{array}{c}0.259^{\mathrm{e}} \\
(0.007) \\
\end{array}$ & $\begin{array}{l}0.124^{\mathrm{bc}} \\
(0.002)\end{array}$ & $\begin{array}{c}0.115^{\mathrm{b}} \\
(0.005)\end{array}$ & $\begin{array}{c}3.16^{\mathrm{ab}} \\
(0.153)\end{array}$ & $\begin{array}{l}0.241^{\mathrm{d}} \\
(0.020)\end{array}$ & $\begin{array}{c}6.60^{\mathrm{d}} \\
(0.259) \\
\end{array}$ & $\begin{array}{c}0.014^{\mathrm{d}} \\
(0.003) \\
\end{array}$ \\
\hline 32 & $\begin{array}{l}0.232^{\mathrm{e}} \\
(0.002)\end{array}$ & $\begin{array}{l}0.118^{c} \\
(0.001)\end{array}$ & $\begin{array}{c}0.120^{\mathrm{b}} \\
(0.006)\end{array}$ & $\begin{array}{c}3.40^{\mathrm{a}} \\
(0.196)\end{array}$ & $\begin{array}{l}0.236^{\mathrm{d}} \\
(0.011)\end{array}$ & $\begin{array}{c}6.70^{\mathrm{d}} \\
(0.248)\end{array}$ & $\begin{array}{l}0.010^{\mathrm{d}} \\
(0.003)\end{array}$ \\
\hline
\end{tabular}

*Means (standard deviation) followed by identical letters are not statistically different ( $\mathrm{p}<0,05$ - Tukey's test); ‘' data not available; $\mathrm{Y}_{\mathrm{P} / \mathrm{Sc}}$ - conversion factor of TOC into $\mathrm{P}(3 \mathrm{HB}) ; \mathrm{Y}_{\mathrm{P} / \mathrm{Sn}}$ - conversion factor of TN into $\mathrm{P}(3 \mathrm{HB})$; $\mathrm{Y}_{\mathrm{X} / \mathrm{Sc}}-$ conversion factor of TOC into cells; $\mathrm{Y}_{\mathrm{X} / \mathrm{Sn}}-$ conversion factor of TN into cells; $\mu_{\mathrm{x}}-$ specific cell growth rate.

Observing the kinetic parameters, it is possible to determine that the highest $\mathrm{P}(3 \mathrm{HB})$ productivity occurred at $20 \mathrm{~h}(0.146 \mathrm{~g} / \mathrm{L} \cdot \mathrm{h})$. However, it does not differ statistically $(\mathrm{p}<0.05)$ from the productivity obtained in $16 \mathrm{~h}(0.137 \mathrm{~g} / \mathrm{L} \cdot \mathrm{h})$. After the $20 \mathrm{~h}$ mark, polymer productivity fell to $0.124 \mathrm{~g} / \mathrm{L} \cdot \mathrm{h}$ at $24 \mathrm{~h}$, reaching a final value of $(0.118 \mathrm{~g} / \mathrm{L} \cdot \mathrm{h})$ at $32 \mathrm{~h}$ of culture. Faccin $e t$ al. [22] have also evaluated kinetic parameters for $\mathrm{P}(3 \mathrm{HB})$ production by $B$. megaterium using sucrose with different kLa profiles and obtained maximum productivity of $0.140 \mathrm{~g} / \mathrm{L} \cdot \mathrm{h}$ after $48 \mathrm{~h}$ when using an agitation speed of $500 \mathrm{rpm}$.

Comparing the results obtained by Faccin et al. [22] with this study, it is possible to observe that while their highest productivity value was similar to the value found during this study, the time necessary to reach peak productivity was considerably longer. A possible cause could be due to aeration conditions, as Faccin et al. [22] kept the culture medium's $\mathrm{O}_{2}$ saturation at $100 \%$ during the whole culture phase, as $\mathrm{O}_{2}$ availability can greatly influence $\mathrm{P}(3 \mathrm{HB})$ production, with data suggesting that higher $\mathrm{O}_{2}$ concentrations cause $B$. megaterium cells metabolism to prioritize tricarboxylic acid cycle pathways, instead of deploying acetylCoA into $\mathrm{P}(3 \mathrm{HB})$ related metabolic routes, as the environmental stress necessary to incentivize polymer accumulation is reduced [42-45]. Still, on the topic of $\mathrm{P}(3 \mathrm{HB})$ productivity, GarcíaCabrera et al. [46] cultivated Rhizobium phaseoli in modified Rhizobium sp medium with glucose and obtained a productivity rate of $12.0 \mathrm{mg} / \mathrm{L} \cdot \mathrm{h}$ after $28 \mathrm{~h}$ when using an agitation speed of $450 \mathrm{rpm}$; furthermore, the maximum $\mathrm{P}(3 \mathrm{HB})$ accumulation rate found under these culture conditions was of $0.34 \mathrm{~g} / \mathrm{L} \cdot \mathrm{h}$. Jayakrishnan et al. [41] have also obtained productivity levels of 4.3 to $13.4 \mathrm{mg} / \mathrm{L} \cdot \mathrm{h}$. Both cases being significantly lower than what has been found using B. megaterium in this study.

As for the other kinetic parameters, a peculiar behavior is found in substrate consumption. For both polymer production and cell growth, TN has a much greater conversion rate than TOC. In the case of polymer formation, the maximum obtained conversion rate for TOC was approximately $0.13 \mathrm{~g} / \mathrm{g}$ from $20 \mathrm{~h}$ to $24 \mathrm{~h}$. TN, however, had a maximum conversion rate of $3.4 \mathrm{~g} / \mathrm{g}$ at $32 \mathrm{~h}$. For cellular production, a similar behavior was observed, with the 
maximum TOC conversion rate being $0.452 \mathrm{~g} / \mathrm{g}$ at $8 \mathrm{~h}$, while the highest TN conversion rate into cells was found to be $8.41 \mathrm{~g} / \mathrm{g}$ at $12 \mathrm{~h}$. Egli [47] points out that this behavior is common in $\mathrm{P}(3 \mathrm{HB})$ producing cultures in which the culture medium contains carbon in excess, with the conversion rates of nitrogen to product or nitrogen to cells being able to reach up to $20 \mathrm{~g} / \mathrm{g}$. Oliveira-Filho et al. [48], for example, also report similar conversion factors to the ones found here, with nitrogen to the cell conversion rate of $7.5 \mathrm{~g} / \mathrm{g}$ when producing $\mathrm{P}(3 \mathrm{HB})$ by growing Burkholderia sacchari LMG 19450 and using xylose as the carbon source. Similarly, Khanna and Srivastava [49] cultivated Ralstonia eutropha NRRL B14690 in an optimized medium with fructose and obtained nitrogen to the biomass conversion rate $10.01 \mathrm{~g} / \mathrm{g}$. Likewise, Faccin [50] estimated $B$. megaterium DSM $32^{\mathrm{T}}$ kinetics and obtained maximum nitrogen to a cell conversion factor of $8.48 \mathrm{~g} / \mathrm{g}$, a value almost identical to the one found here with $B$. megaterium ATCC 14581.

Lastly, regarding the specific cell growth rates, the highest value found was $0.61 \mathrm{~h}^{-1}$, at $8 \mathrm{~h}$, with the growth rate slowing down to $0.01 \mathrm{~h}^{-1}$ after $32 \mathrm{~h}$ of culture. This behavior matches the growth curve presented in Figure 3, as most of the exponential phases occurred in the period between $4 \mathrm{~h}$ to $12 \mathrm{~h}$. Shahid et al. [51] obtained similar $\mu_{\mathrm{x}}$ values when cultivating $B$. megaterium DSM $32^{\mathrm{T}}\left(0.47 \mathrm{~h}^{-1}\right)$, B. megaterium DSM $90\left(0.51 \mathrm{~h}^{-1}\right)$, and B. megaterium DSM $509\left(0.44 \mathrm{~h}^{-1}\right)$ for $24 \mathrm{~h}$ to produce $\mathrm{P}(3 \mathrm{HB})$ in mineral medium with glucose. Likewise, Dalsasso et al. [52] have also calculated $\mathrm{P}^{\prime}$ s kinetic parameters (3HB) production by Cupriavidus necator using sugarcane vinasse and molasses as the carbon source. They have obtained maximum $\mu_{\mathrm{x}}$ ranging from $0.19 \mathrm{~h}^{-1}$ to $0.37 \mathrm{~h}^{-1}$ in different culture medium compositions. In contrast, GarcíaCabrera [46] also evaluated $\mathrm{P}(3 \mathrm{HB})$ production kinetics by Rhizobium phazeoli and obtained specific growth rates ranging from $0.09 \mathrm{~h}^{-1}$ to $0.16 \mathrm{~h}^{-1}$. This corroborates that $B$. megaterium has good potential as a $\mathrm{P}(3 \mathrm{HB})$ producer due to its high growth rate, reducing total culture time.

Considering the data obtained from the culture of $B$. megaterium using agroindustry byproducts, it is evident that they can be used as culture media in $\mathrm{P}(3 \mathrm{HB})$ production, however, further studies should be conducted since, as seen in Figure 3, the amount of TOC present at the final point of culture is close to $80 \mathrm{~g} / \mathrm{L} \cdot \mathrm{h}$. As such, experiments using medium recycling, with the removal of $B$. megaterium cells, possibly via filtration, could also be explored.

\section{Conclusions}

The results obtained in this work successfully demonstrate that confectionery wastewater (CWW) alongside rice parboiling water (RPW) can successfully be used as culture medium components for $\mathrm{P}(3 \mathrm{HB})$ production. Both byproducts are still seen as a waste by most industries that produce them, and their use as culture media components might offer an alternative income to the industries that produce them while at the same time reducing overall $\mathrm{P}(3 \mathrm{HB})$ production costs. CWW and RPW in bioreactor cultures at $500 \mathrm{rpm}$ were able to yield $7.55 \mathrm{~g} / \mathrm{L} \cdot \mathrm{h}$ of dry biomass, with $50.06 \%$ of that being accumulated $\mathrm{P}(3 \mathrm{HB})(3.78 \mathrm{~g} / \mathrm{L} \cdot \mathrm{h})$. Still, further studies are necessary to fully optimize the process and find alternatives to reduce residual COT amount still present in the cultures.

\section{Funding}

This study was financed by Coordination for the Improvement of Higher Education Personnel (CAPES), Brazil [Financial Code 001]. 


\section{Acknowledgments}

The authors thank the National Council for Scientific and Technological Development (CNPq), Coordination for the Improvement of Higher Education Personnel (CAPES), and Research Support Foundation of the State of Rio Grande do Sul (FAPERGS).

\section{Conflicts of Interest}

\section{The authors would like to declare that there is no conflict of interest regarding this study.}

\section{References}

1. Khanna, S.; Srivastava, A.K. Recent advances in microbial polyhydroxyalkanoates. Process Biochem. 2005, 40, 607-619, https://doi.org/10.1016/j.procbio.2004.01.053.

2. Pakalapati, H.; Chang, C.; Show, P.L.; Arumugasamy, S.K.; Lan, J.C. Development of polyhydroxyalkanoates production from waste feedstocks and applications. J. Biosci. Bioeng. 2018, 126, 282-292, https://doi.org/10.1016/j.jbiosc.2018.03.016.

3. Fernandes, I.A.; Nyari, N.L.; Oliveira, J.V.; Rigo, E.; Souza, M.C.M.; Goncalves, L.R.B.; Pergher, S.B.C.; Oliveira, D. Nanoparticles of poly(hydroxybutyrate- co -hydroxyvalerate) as support for the immobilization of Candida antarctica lipase (Fraction B). Quím. Nova 2014, 37, 331-336, http://dx.doi.org/10.5935/01004042.20140055.

4. Lin, Y.-Y.; Chen, P.T. Development of polyhydroxybutyrate biosynthesis in Bacillus subtilis with combination of PHB-associated genes derived from Ralstonia eutropha and Bacillus megaterium. J. Taiwan Inst. Chem. Eng. 2017, 79, 110-115, https://doi.org/10.1016/J.JTICE.2017.02.030.

5. Israni, N.; Shivakumar, S. Combinatorial screening of hydrolytic enzyme/s and PHA producing Bacillus Spp., for cost effective production of PHAS. Int. J. Pharma Bio Sci. 2013, 4, 934-945.

6. Mohapatra, S.; Maity, S.; Dash, H.R.; Das, S.; Pattnaik, S.; Rath, C.C.; Samantaray, D. Bacillus and biopolymer: Prospects and challenges. Biochem. Biophys. Reports. 2017, 12, 206-213, https://doi.org/10.1016/J.BBREP.2017.10.001.

7. Park, S.J.;. Choi, J.I.;. Lee, S.Y. Short-chain-length polyhydroxyalkanoates: Synthesis in metabolically engineered Escherichia coli and medical applications. J. Microbiol. Biotechnol. 2005, 15, 206-215.

8. Kumar, P.; Patel, S.K.S.; Lee, J.; Kalia, V.C. Extending the limits of Bacillus for novel biotechnological applications. Biotechnol. Adv. 2013, 31, 1543-1561, https://doi.org/10.1016/j.biotechadv.2013.08.007.

9. Faccin, D.J.L.; Martins, I.; Cardozo, N.; Medeiros, S.; Rech, R.; Ayub, M.A.Z.; Alves, T.L.M.; Gambetta, R.; Resende, S.A. Optimization of C:N ratio and minimal initial carbon source for poly(3-hydroxybutyrate) production by. by Bacillus megaterium. J. Chem. Technol. Biotechnol. 2009, 84, 1756-1761, https://doi.org/10.1002/jctb.2240.

10. Kavitha, G.; Rengasamy, R.; Inbakandan, D. Polyhydroxybutyrate production from marine source and its application. Int. J. Biol. Macromol. 2018, 111, 102-108, https://doi.org/10.1016/j.ijbiomac.2017.12.155.

11. García, A.; Pérez, D.; Castro, M.; Urtuvia, V.; Castillo, T.; Díaz-Barrera, A.; Espín, G.; Peña, C. Production and recovery of poly-3-hydroxybutyrate [P(3HB)] of ultra-high molecular weight using fed- batch cultures of Azotobacter vinelandii OPNA strain. J Chem. Technol. Biotechnol. 2019, 94, 1853-1860, https://doi.org/10.1002/jctb.5959.

12. Díaz-Barrera, A.; Urtuvia, V.; Padilla-Córdova, C.; Peña, C. Poly(3-hydroxybutyrate) accumulation by Azotobacter vinelandii under different oxygen transfer strategies. J. Industrial Microbiol. Biotechnol. 2019, 46, 13-19, https://doi.org/10.1007/s10295-018-2090-9.

13. Gómez-Hernández, E.; Salgado-Lugo, H.; Segura, D.; García, A.; Díaz-Barrera, A.; Peña, C. Production of Poly-3-Hydroxybutyrate (P3HB) with ultra-high molecular weight (uhmw) by mutant strains of azotobacter vinelandii under microaerophilic conditions. Appl. Biochem. Biotechnol. 2021, 193, 79-95, https://doi.org/10.1007/s12010-020-03384-w.

14. Cal, A.J.; Kibblewhite, R.E.; Dirk Sikkema, W.; Torres, L.F.; Hart-Cooper, W.M.; Orts, W.J.; Lee, C.C. Production of polyhydroxyalkanoate copolymers containing 4-hydroxybutyrate in engineered Bacillus megaterium. Int. J. Biol. Macromol. 2021, 168, 86-92, https://doi.org/10.1016/j.ijbiomac.2020.12.015

15. Schmid, M.; Raschbauer, M.; Song, H.; Bauer, C.; Neureiter, M. Effects of nutrient and oxygen limitation, salinity and type of salt on the accumulation of poly(3-hydroxybutyrate) in Bacillus megaterium uyuni S29 with sucrose as a carbon source. New Biotechnol. 2021, 61, 137-144, https://doi.org/10.1016/j.nbt.2020.11.012.

16. Mohanrasu, K.; Guru Raj Rao, R.; Dinesh, Kunyu Zhang, G.H.; Siva Prakash, G.; Dong-Po Song, Sudhakar Muniyasamy, Pugazhendhi, A.; Jeyakanthan, J.; Arun, A. Optimization of media components and culture conditions for polyhydroxyalkanoates production by Bacillus megaterium. Fuel 2020, 271, https://doi.org/10.1016/j.fuel.2020.117522. 
17. Li, J.; Yang, Z.; Zhang, K.; Liu, M.; Liu, D.; Yan, X.; Si, M.; Shi, Y. Valorizing waste liquor from dilute acid pretreatment of lignocellulosic biomass by Bacillus megaterium B-10. Ind. Crop. Prod. 2021, 161, https://doi.org/10.1016/j.indcrop.2020.113160.

18. Mohapatra, S.; Pattnaik, S.; Maity, S.; Mohapatra, S.; Sharma, S.; Akhtar, J.; Pati, S.; Samantaray, D.P.; Varma, A. Comparative analysis of PHAs production by Bacillus megaterium OUAT 016 under submerged and solid-state fermentation. Saudi J. Biol. Sci. 2020, 27, 1242-1250, https://doi.org/10.1016/j.sjbs.2020.02.001.

19. Silambarasan, S.; Logeswari, P.; Sivaramakrishnan, R.; Pugazhendhi, A.; Kamaraj, B.; Ruiz, A.; Ramadoss, G.; Cornejo, P. Polyhydroxybutyrate production from ultrasound-aided alkaline pretreated finger millet straw using Bacillus megaterium strain CAM12. Biores. Technol. 2021, 325, https://doi.org/10.1016/j.biortech.2020.124632.

20. White, C.; Laird, D.W.; Hughes, L.J. From carbon waste to carbon product: Converting oxalate to polyhydroxybutyrate using a mixed microbial culture. J. Environ. Chem. Eng. 2017, 5, 2362-2365, https://doi.org/10.1016/j.jece.2017.04.040.

21. Thomas, S.; Balakrishnan, P.; Sreekala, M.S. Fundamental Biomaterials: Polymers. $1^{\text {st }}$ ed., Woodhead Publihing, Amsterdam, 2018, https://doi.org/10.1016/C2016-0-03544-1.

22. Faccin, D.J.L.; Rech, R.; Secchi, A. R.; Cardozo, N.S.M.; Ayub, M.A.Z. Influence of oxygen transfer rate on the accumulation of poly(3-hydroxybutyrate) by Bacillus megaterium. Process Biochem. 2013, 48, 420425, https://doi.org/10.1016/j.procbio.2013.02.004.

23. Childs, N.; Raszap, S. Rice Outlook, 2017. https://www.ers.usda.gov/webdocs/outlooks/85722/rcs17k.pdf?v=9268.2 (accessed November 26, 2017).

24. ABICCAB. Associação Brasileira da Indústria de Chocolates, Cacau, Amendoim, Balas e Derivados, Associados Balas \& Derivados, Bras. Sweets Snacks. 2020, 1, https://www.brasilsns.org.br/en/industria/ .

25. Papadaki, A.; Fernandes, K.V.; Chatzifragkou, A.; Aguieiras, E.C.G.; Da Silva, J.A.C.; Fernandez-Lafuente, R.; Papanikolaou, S.; Koutinas, A.; Freire, D.M.G. Bioprocess development for biolubricant production using microbial oil derived via fermentation from confectionery industry wastes. Bioresour. Technol. 2018, 267, 311-318, https://doi.org/10.1016/j.biortech.2018.07.016.

26. Maqbool, F.; Bhatti, Z.A.; Nazir, H.; Qayyum, S.; Zhao, Y.-G.; Khan, I.; Kamal, R.; Pervez, A.Confectionary wastewater treatment through upflow microbial fuel cell. Desalin. Water Treat. 2017, 99, 248-254, https://doi.org/10.5004/dwt.2017.21695.

27. De Araújo, R.; Nascimento, L.; Helena, M.; Estevam, M.; Edmilson, H.; Freitas, S.; Manhke, L.C.; Cavalcanti, M.A.; De Santana, K.V.; Elesbão, A.; Alberto, C.; Silva, A. Aproveitamento da água de maceração de milho para produção de compostos bioativos por Aspergillus niger. E-Xacta. 2015, 8, 15-29, http://dx.doi.org/10.18674/exacta.v8i1.1421.

28. Mukherjee, C.; Chowdhury, R.; Sutradhar, T.; Begam, M.; Ghosh, S.M.; Kumar Basak, S.; Ray, K. Parboiled rice effluent: A wastewater niche for microalgae and Cyanobacteria with growth coupled to comprehensive remediation and phosphorus biofertilization. Algal Res. 2016, 19, 225-236, https://doi.org/10.1016/j.algal.2016.09.009.

29. Faccin, D.J.L.; Corrêa, M.P.; Rech, R.; Ayub, M.A.Z.; Secchi, A.R.; Cardozo, N.S.M. Modeling P(3HB) production by Bacillus megaterium. J. Chem. Technol. Biotechnol. 2012, 87, 325-333, https://doi.org/10.1002/jctb.2713.

30. Colet, R.; Urnau, L.; Bampi, J.; Zeni, J.; Dias, B.B.; Rodrigues, E.; Jacques, R.A.; Di Luccio, M.; Valduga, E. Use of low-cost agro products as substrate in semi-continuous process to obtain carotenoids by Sporidiobolus salmonicolor. Biocatal. Agric. Biotechnol. 2017, 11, 268-274, https://doi.org/10.1016/j.bcab.2017.07.015.

31. Dalsasso, R.R.; Pavan, F.A.; Bordignon, S.E.; De Aragão, G.M.F.; Poletto, P. Polyhydroxybutyrate (PHB) production by Cupriavidus necator from sugarcane vinasse and molasses as mixed substrate. Process Biochemistry, 2019, 85, 12-18, https://doi.org/10.1016/j.procbio.2019.07.007.

32. Bailey, J.; Bailey, J.E.; Ollis, D.F.; Simpson, R.J.; Ollis, D.F. Biochemical Engineering Fundamentals. $2^{\text {nd }}$ ed., McGraw-Hill, New York, 1986.

33. Hassemer, G.S. Produção de $\mathrm{P}(3 \mathrm{HB})$ por Bacillus megaterium utilizando permeado de soro de leite, Universidade Federal do Rio Grande do 2016. http://www.lume.ufrgs.br/bitstream/handle/10183/157486/001016827.pdf?sequence=1 (accessed June 13, 2018).

34. Riis, V.; Mai, W. Gas chromatographic determination of poly- $\beta$-hydroxybutyric acid in microbial biomass after hydrochloric acid propanolysis. J. Chromatogr. A. 1988, 445, 285-289, https://doi.org/10.1016/S00219673(01)84535-0.

35. Suarez, C.A.G.; Montano, I.D.C.; Nucci, E.R.; Iemma, M.R. C.; Giordano, R.L.C.; Giordano, R.C. Assessment of the Metabolism of Different Strains of Bacillus megaterium. Brazilian Arch. Biol. Technol. 2012, 55, 485-490, https://doi.org/10.1590/S1516-89132012000400001.

36. Omar, S.; Rayes, A.; Eqaab, A.; Voss, I.; Steinbuchel, A. Optimization of cell growth and poly(3hydroxybutyrate) accumulation on date syrup by a Bacillus megaterium strain. Biotechnol. Lett. 2001, 23, 1119-1123, https://doi.org/10.1023/A:1010559800535. 
37. Grumezescu, A.M.; Holban, M.A. Biopolymers for Food Design. $1^{\text {st }}$ ed., Academic Press, London, 2018.

38. Saratale, R.G.; Cho, S.K.; Saratale, G.D.; Ghodake, G.S.; Bharagava, R.N.; Kim, D.S.; Nair, S.; Shin, H.S. Efficient bioconversion of sugarcane bagasse into polyhydroxybutyrate (PHB) by Lysinibacillus sp. and its characterization. Bioresour. Technol. 2021, 324, https://doi.org/10.1016/j.biortech.2021.124673.

39. Naresh Kumar, A.; Chatterjee, S.; Hemalatha, M.; Althuri, A.; Min, B.; Kim, S.H.; Venkata Mohan, S. Deoiled algal biomass derived renewable sugars for bioethanol and biopolymer production in biorefinery framework. Bioresour. Technol. 2020, 296, https://doi.org/10.1016/j.biortech.2019.122315.

40. Amini, M.; Yousefi-Massumabad, H.; Younesi, H.; Abyar, H.; Bahramifar, N. Production of the polyhydroxyalkanoate biopolymer by Cupriavidus necator using beer brewery wastewater containing maltose as a primary carbon source. J. Environ. Chem. Eng. 2020, 8, https://doi.org/10.1016/J.JECE.2019.103588.

41. Jayakrishnan, U.; Deka, D.; Das, G. Influence of inoculum variation and nutrient availability on polyhydroxybutyrate production from activated sludge. Int. J. Biol. Macromol. 2020, 163, 2032-2047, https://doi.org/10.1016/j.ijbiomac.2020.09.061.

42. Third, K.A.; Newland, M.; Cord-Ruwisch, R. The effect of dissolved oxygen on PHB accumulation in activated sludge cultures. Biotechnol. Bioeng. 2003, 82, 238-250, https://doi.org/10.1002/bit.10564.

43. Yeo, J.C.C.; Muiruri, J.K.; Warintorn, T.; Li, Z.; He, C. Recent advances in the development of biodegradable PHB-based toughening materials: Approaches, advantages and applications. Mater. Sci. Eng. C 2017, 92, 1092-1116, https://doi.org/10.1016/j.msec.2017.11.006.

44. Pradella, J.G.d.C.; Taciro, M.K.; Mateus, A.Y.P. High-cell-density poly (3-hydroxybutyrate) production from sucrose using Burkholderia sacchari culture in airlift bioreactor. Bioresour Technol. 2010, 101, 83558360, https://doi.org/10.1016/j.biortech.2010.05.046.

45. Sirohi, R.; Prakash Pandey, J.; Kumar Gaur, V.; Gnansounou, E.; Sindhu, R. Critical overview of biomass feedstocks as sustainable substrates for the production of polyhydroxybutyrate (PHB). Bioresour Technol. 2020, 311, https://doi.org/10.1016/j.biortech.2020.123536.

46. García-Cabrera, R.I.; Valdez-Cruz, N.A.; Blancas-Cabrera, A.; Trujillo-Roldán, M.A. Oxygen transfer rate affect polyhydroxybutyrate production and oxidative stress response in submerged cultures of Rhizobium phaseoli. Biochem. Eng. J. 2020, 162, https://doi.org/10.1016/j.bej.2020.107721.

47. Egli, T. Microbial growth and physiology: a call for better craftsmanship. Front. Microbiol. 2015, 06, https://doi.org/10.3389/fmicb.2015.00287.

48. Oliveira-Filho, E.R.; Silva, J.G.P.; de Macedo, M.A.; Taciro, M.K.; Gomez, J.G.C.; Silva, L.F. Investigating nutrient limitation role on improvement of growth and Poly(3-Hydroxybutyrate) accumulation by Burkholderia sacchari LMG 19450 from xylose as the sole carbon source. Front. Bioeng. Biotechnol. 2020, 7, https://doi.org/10.3389/fbioe.2019.00416.

49. Khanna, S.; Srivastava, A.K. A Simple Structured Mathematical Model for Biopolymer (PHB) Production. Biotechnol. Prog. 2008, 21, 830-838, https://doi.org/10.1021/bp0495769.

50. Faccin, D.J.L.; Rech, R.; Secchi, A.R.; Cardozo, N.S.M.; Ayub, M.A.Z. Influence of oxygen transfer rate on the accumulation of poly(3-hydroxybutyrate) by Bacillus megaterium. Process Biochem. 2013, 48, 420-425, https://doi.org/10.1016/j.procbio.2013.02.004.

51. Shahid, S.; Mosrati, R.; Ledauphin, J.; Amiel, C.; Fontaine, P.; Gaillard, J.-L.; Corroler, D. Impact of carbon source and variable nitrogen conditions on bacterial biosynthesis of polyhydroxyalkanoates: evidence of an atypical metabolism in Bacillus megaterium DSM 509. J. Biosci. Bioeng. 2013, 116, 302-308, https://doi.org/10.1016/j.jbiosc.2013.02.017.

52. Dalsasso, R.R.; Pavan, F.A.; Bordignon, S.E.; Aragão, G.M.F. de; Poletto, P. Polyhydroxybutyrate (PHB) production by Cupriavidus necator from sugarcane vinasse and molasses as mixed substrate. Process Biochem. 2019, 85, 12-18, https://doi.org/10.1016/j.procbio.2019.07.007. 